\title{
ОНОМАСТИЧНИЙ ОСЕРЕДОК МИХАЙЛА ТОРЧИНСЬКОГО
}

у статті описано особливості дослідницької й освітньої діяльності украйнського ономаста Михайла Миколайовича Торчинського як засновника самостійного ономастичного иентру, окремої української ономастичної школи. Проаналізовано навчально-виховну діяльність ученого й колективу його підопічних, схарактеризовано його методологічні засади, спроєктовані на достідження пропріальної лексики, визначено перспективу розвитку ономастичних досліджень, що простежується в межах зазначеного осередка. Дослідження скорельовано з основними критеріями, щз визначають статус наукової школи. Аналіз науково-виховної діяльності М. Торчинського і його вихованців дав змогу дійти висновку, що М. Торчинський заснував потужний ономастичний осередок, який формує його наукову школу, що активно розвивається.

Ключові слова: ономастичний осередок, наукова школа, українські ономастичні школи, Михайло Торчинський, Хмельницький національний універcumem.

Janczura D. Onomastic Hub of Mykhailo Torchynskyi. The rapid development of onomastics as a field of study, the number of onomastic units and their widespread use, the peculiarities of the system of naming expressions and their multifunctionality have all led to the establishing of separate onomastic hubs or research schools in Ukraine, as well as in other countries. Each of the Ukrainian onomastic environments is grounded in a certain methodology, focused on studying certain types of naming expressions and forms a certain terminological system. Among the recently founded Ukrainian onomastic hubs, a research centre headed by Mykhailo Torchynskyi occupies a special place. The present study is worth pursuing now, as, first of all, the onomastic hub of Mykhailo Torchynskyi is relevantly new but strong, and it is on the basis of this hub that the new onomastic school of thought is being formed. Secondly, the number of studies devoted to the contributions of separate Ukrainian onomastic schools is poor, whereas each onomastician should know about the achievements of the key Ukrainian research centres and schools of thought. The aim of the article is to highlight the peculiarities of Torchynksyis research work connected with the establishment of the onomastic hub and the onomastic research school. The following tasks are related to the aim of the study: 1) to analyse the peculiarities of Torchynskyi's research work, 2) to describe the direction of research activities carried out by his followers, 3) to point to the unique character of Torchynskyi's research hub in comparison with the other onomastic schools in Ukraine. The present research 
has a descriptive character, since mostly the descriptive and interpretative methods have been used. The prestigious status of Mykhailo Torchynskyis hub can be credited to a wide range of interests of the onomastician and his followers, the development of unique study courses, the formulation of tailored methodological principles, the popularisation of the research findings in specialised journals and at conferences, etc. The school of Mykhailo Torchynskyi has many prospects, which is not only obvious from the practical plans of the onomastician and his team to develop the electronic version of the dictionary of the Ukrainian onomastic terminology, but also from the multifaceted research of different types of naming expressions (traditional and new ones), which may become the foundation for the new theoretical studies and lexicographic works both in Ukraine and abroad.

Key words: onomastic hub, scientific school, Ukrainian onomastics schools, Mykhailo Torchynskyi, Khmelnytskyi National University.

\section{Вступ}

Ономастика - це наука, актуальність якої не зменшується впродовж тривалого часу розвитку мовознавства, оскільки власні назви супроводжують людину протягом усього життя; іï ономастикон безперервно поповнюється, тому важливо, щоб цей унікальний пласт лексики постійно досліджувався. Численність пропріальних одиниць, їхні особливості, різноманітність, багатофункційність - усе це чинники, що призвели до появи в Україні різних ономастичних осередків, ономастичних наукових шкіл, у межах яких досліджуються окремі категорії власних назв, розширюється ономастична терміносистема, розробляються новаторські методи та методики, оновлюється методологія та ін.

Сьогодні в Україні широко відомі такі ономастичні наукові школи, як Одеська (Ю. Карпенко, М. Зубов, О. Карпенко, Т. Крупеньова, Л. Фоміна), Ужгородська (П. Чучка, Л. Белей, О. Белей, С. Пахомова, М. Сюсько), Донецька (Е. Кравченко, Г. Лукаш, Є. Отін, О. Філатова), Київська (С. Вербич, І. Желєзняк, В. Лучик, В. Шульгач). Мають тривалу традицію функціювання й Львівський, Тернопільський, Чернівецький ономастичні осередки, діяльність яких була окреслена авторкою цієї статті раніше (див. Янчура, 2018).

Аналіз останніх досліджень і публікацій свідчить про недостатню кількість наукових праць, присвячених вивченню діяльності українських ономастичних осередків. На сьогодні опис цілісної картини цієї діяльності не репрезентований. Узагальнену інформацію про деякі 
ономастичні школи в Україні запропонувала Д. Янчура (2018). Діяльність окремих українських ономастичних центрів, колективів чи конкретних дослідників висвітлені в працях представників цих осередків (Карпенко, Фоміна, Зубов \& Калінкін, 2012; Купчинська, 2019; Торчинський, 2019). У деяких наукових розвідках йдеться про перспективи української ономастики, запропоновано інформацію про досягнення окремих дослідників (Вербич, 2010; Дергач, 2008; Зубко, 2007; Лучик, 2011). Популярними $є$ також розвідки, присвячені окремим ученим у зв'язку з їхніми ювілеями чи завершенням наукової діяльності.

Цю наукову студію вважаємо актуальною, оскільки ономастичний осередок М. Торчинського почав стрімко розвиватися не лише завдяки плідній праці названого ономаста, але й завдяки активній дослідницькій діяльності його учнів, послідовників - науковців Хмельницького національного університету, що розширюють і поглиблюють методологічний доробок ученого, утілюють його ідеї в життя, формуючи нову наукову ономастичну школу.

Мета дослідження - виокремити особливості дослідницької й виховної роботи М. Торчинського як керівника окремого ономастичного осередка, нової української ономастичної школи. 3 метою співвідносяться такі завдання: 1) окреслити основні риси наукової й виховної діяльності М. Торчинського, 2) описати вектор дослідницької роботи колективу підопічних ученого, що здійснюється на базі Хмельницького національного університету; 3) показати шлях створення нового українського наукового ономастичного осередку та формування нової ономастичної школи.

Ця наукова розвідка розширює інформацію про українські ономастичні осередки та школи, що відображена в авторській статті, опублікованій у польському журналі «Studia Ukrainica Posnaniensia» (Янчура, 2018).

\section{Методи та методики дослідження}

Розвідка має оглядовий та дескриптивний характер. У дослідженні використано описовий та інтерпретативний методи, що спрямовані на аналіз наукових здобутків М. Торчинського й колективу його підопічних, які репрезентують активний сучасний український ономастичний осередок, нову наукову школу, що розбудовується на базі Хмельницького національного університету. 


\section{Результати та дискусії}

Михайло Торчинський - доктор філологічних наук, професор, завідувач кафедри української філології Хмельницького національного університету, член Української ономастичної комісії. Дисертацію на здобуття наукового ступеня кандидата філологічних наук лінгвіст присвятив ойконімії Південно-Західного Поділля (1993), яку написав під науковим керівництвом доктора філологічних наук, професора С. Бевзенка. Учений схарактеризував назви населених пунктів указаної території з урахуванням семантики твірної основи, способів творення й мотиваційних відношень. 2010 року дослідник захистив дисертацію «Онімна лексика української мови. Типологія й функціювання онімної лексики» на здобуття наукового ступеня доктора філологічних наук, у якій запропонував оновлену класифікаційну структуру ономастикону української мови, розробив нову схему аналізу пропріальних одиниць, значно розширивши термінологічну систему української ономастики та розширивши ії методологію.

Як ономаст М. Торчинський відомий саме завдяки його сміливій спробі створення оновленої класифікації онімної лексики, його намаганню збагатити терміносистему ономастики шляхом виокремлення нових типів онімів, щоправда, на думку деяких дослідників, ця класифікація дещо суб'єктивна, «індивідуально-авторська», і надто деталізована (див. Бучко \& Ткачова, 2012; Лучик, 2010). Наукова діяльність ученого має вияв у достатньо великій кількості грунтовних публікацій, які демонструють широкий спектр його ономастичних зацікавлень, що активно популяризуються на конференціях різних рівнів, виявляються в поширенні його ономастичних ідей серед молодих учених України. Зазначене дає право стверджувати, що М. Торчинський - це сформований науковий лідер, що започаткував формування ономастичної наукової школи в Хмельницькому національному університеті на базі відповідного ономастичного осередку.

Як зауважує Т. Космеда, «навчання в межах кожного конкретного вищого навчального закладу в українському національному університетському просторі, прилучення до української наукової традиції нерозривно пов'язане з пошуком нового знання, нових методів чи методик вирішення системи завдань, формування відповідної метамови, термінологічного апарату й под. з опертям на національну традицію (...)» (Космеда, 2017: 177-178). Названа дослідниця пропонує 
дефініцію поняття наукова школа, порівн.: «Це творча співдружність учених, об'єднаних спільністю методологічних підходів до вирішення наукових проблем, особливим стилем науково-дослідної роботи, науковою ідеологією, спільністю наукового мислення, ідей і методів їхньої реалізації» (Космеда, 2017: 181). Усе перераховане чітко простежуємо в науковому осередку М. Торчинського, що й засвідчує факт формування й становлення нової ономастичної школи в Україні. Наголосимо, що раніше на брак ономастичних українських осередків саме в центральні частині України вказували українські ономасти в оглядових публікаціях щодо специфіки розвитку українських ономастичних шкіл (див., напр., Стрижак, 1980). Тому можна вважати, що зазначена прогалина має тенденцію до ліквідації.

Дослідження здійснюватимемо на основні головних критеріїв, що визначають статус наукових шкіл:

1) наявність засновника-лідера, що сформулював суть наукового підходу до предмета дослідження й розробив відповідні методологічні принципи для дослідницької роботи;

2) подібність наукових позицій його учнів, що прийняли методологію наукового керівника й вироблені підходи до аналізу конкретних мовних явищ;

3) єдність місця діяльності;

4) новизна й оригінальність методологічного підходу, що сформульовані цією школою (Купчинська, 2019: 3-4; Алефиренко, 2005: 23).

М. Торчинський зауважує, що його діяльність в межах ономастичної традиції Хмельницького національного університету «грунтується на попередніх здобутках колективів передусім двох кафедр - української філології та слов’янської філології» (Торчинський, 2019: 5). Виконання держбюджетної теми «Структура онімного простору української мови» зумовило вихід у світ монографії дослідника з тією самою назвою (Торчинський, 2008) та «Словника власних географічних назв Хмельницької області» (Торчинський \& Торчинська, 2008). У 2009 році вийшла друком монографія «Структура онімного простору української мови. Частина друга. Функціонування власних назв», що довершила дисертаційне дослідження автора на здобуття наукового ступеня доктора філологічних наук. Через рік М. Торчинський видав навчальний посібник «Українська ономастика» (2010), за яким сьогодні вивчають ономастику студенти українських вишів. 
Названі вище праці М. Торчинського користуються великою популярністю серед мовознавців: кількість цитувань ${ }^{1}$ монографії «Структура онімного простору української мови» (2008) сягає позначки 142, дисертаційну роботу про структуру, типологію й функціювання онімної лексики української мови (2010) процитовано 65 разів, словник і навчальний посібник - 21 раз. Це засвідчує актуальність досліджень ономаста та їхню високу якість, затребуваність в українському науковому просторі.

Діапазон наукових зацікавлень ономаста, як зазначалося, досить широкий. Початки дослідницької діяльності вченого були спрямовані на вивчення топонімії Південно-Західного Поділля (2002-2003), згодом він досліджував поетоніми й фолькорні власні назви (2005-2006), особливості функціювання онімів у різних стилях мовлення (2006). Чимало зусиль було докладено вивченню денотативної структури топонімікону, антропонімікону, ергонімії, оронімії чи псевдонімії української мови, вияву тенденцій номінативного процесу в системі зазначених власних назв. Хоч зауважимо, що сьогодні популярна інша теорія М. Толстого, що декларує наявність у власної назви значення, що має не денотативно-сигніфікативну природу, а прагматичну (Толстой, 1997). Важливо, що М. Торчинський ретельно вивчав функції, ознаки й структуру власних назв з урахуванням системи параметрів. У полі зору вченого були й назви опер, балетних вистав, найменування українських засобів масової комунікації. В останні роки увага дослідника сфокусована на питанні, що стосується кількісної характеристики різних розрядів онімів.

М. Торчинський активно займається підготовкою наукових кадрів вищої кваліфікації. 3-поміж учнів М. Торчинського, що розробляють ономастичну проблематику, назвемо I. Гонцу, яка захистила кандидатську дисертацію «Ойконімія Черкащини» (2006). Ця дослідниця - авторка «Словника ойконімів Уманщини» (Гонца, 2017) як першого системного дослідження поселень Уманщини, у якому містяться історичні, географічні та етимологічні відомості про ойконімікон зазначеного регіону (Гонца, 2017: 2).

Під керівництвом М. Торчинського дисертацію на здобуття наукового ступеня кандидата філологічних наук на тему «Антропонімія Уманщини XVII - початку XXI ст.» захистила Ю. Фернос (Блажчук,

1 Відомості за Google Scholar Citations станом на 28 січня 2020 року. 
2008). Вона дослідила лексичну базу, мотиваційні відношення та словотвірну будову прізвищевих назв і прізвищ Уманщини.

2017 року кандидатську дисертацію захистила чергова учениця М. Торчинського - Н. Григорук. Тема ії наукової розвідки - «Власні назви спортивних команд: структура, походження, функціювання в українській мові». Дисертантка сфокусувала увагу на багатоаспектному дослідженні ергонімів (точніше командонімів), розширивши ономастичну термінологію.

Нещодавно під керівництвом М. Торчинського дисертацію на здобуття наукового ступеня кандидата філологічних наук на тему «Прізвищеві назви і прізвища Центральної Хмельниччини XVII-XXI ст.» успішно захистила О. Ющишина (2019), а також А. Янчишин (2019), що студіював проблему «Власні назви промислових товарів: типологія, походження і функціонування».

Проблематику ономастики в різних аспектах нині плідно досліджують аспіранти й викладачі кафедри слов'янської й української мови ХНУ, де працює лідер ономастичного осередку Хмельницького національного університету. Це, зокрема, Л. Зубар, який проєктує увагу на пропріативи, що функціюють у текстах українських письменників-фантастів; І. Ординську приваблює мікротопонімія північної Хмельниччини; Л. Терещенко досліджує поетоніми в українських байках XIX-XX ст.; Я. Янчишина - мікротопонімію центральної Хмельниччини (див. Торчинський, 2019).

Цілком закономірно, що в науковому періодичному виданні ХНУ «Актуальні проблеми філології та перекладознавства» «ономастична тематика є однією з основних» (Торчинський, 2019: 6).

Увагу привертає й навчально-виховна активність ономаста: дослідник $є$ керівником студентської наукової групи «Ономастичні студії» та автором навчального курсу «Українська ономастика», що його викладають студентам-філологам як додатковий курс у циклі мовознавчих дисциплін. Цей авторський курс «покликаний ознайомити студентів з особливостями функціювання пропріальних одиниць у практиці мовної діяльності людини. Мета цього курсу - вивчення закономірностей розвитку й функціювання власних назв у структурі мови. Завдання - ознайомлення з історією вивчення власних назв, особливостями структурування онімного простору, найбільш характерними ознаками онімів, основними методами наукового дослідження 
пропріативів» (Українська ономастика). Крім того, у вступі до свого навчального посібника дослідник справедливо зауважив, що «незважаючи на давні традиції вивчення, до сьогодні відсутні підручники й посібники, у яких би науково достовірно, об'ємно, чітко, доступно було описано особливості власних назв як специфічних мовних одиниць, що мають диференційні особливості насамперед у творенні та функціюванні» (Торчинський, 2010: 7). Як видається, до цього часу навчальний посібник М. Торчинського є чи не єдиним подібним посібником в українському навчальному просторі.

М. Торчинський сформулював найближче завдання ономастичного осередку ХНУ, що функціює під його керівництвом: «е завершення експериментального „Словника української ономастичної термінології” (принаймні електронної версії), охоплення всієї області комплексним вивченням антропонімів, топонімів та ергонімів, аналіз тих розрядів онімної лексики, що ще не були об’єктом серйозних монографічних досліджень» (Торчинський, 2019: 8).

\section{Висновки}

Розвиток ономастичних студій в Україні сприяв становленню низки ономастичних осередків, формуванню й розвитку ономастичних наукових шкіл, серед яких сьогодні найбільш потужними вважають Одеську, Ужгородську, Донецьку, Київську. Кожна ономастична школа має свою наукову ідеологію, відповідну методологію, актуальні вектори дослідницької діяльності.

Хмельницький ономастичний осередок М. Торчинського має беззаперечні підстави для виокремлення в самостійну наукову ономастичну школу, що має власний дослідницький предмет, напрям, метамову, методологію, перспективу, про що свідчить широкий діапазон наукових зацікавлень керівника, зокрема це: 1) навчання й виховання кваліфікованих дослідників, починаючи зі студентської молоді, 2) розробка авторського курсу для студентів, активність і керування студентськими групами в рамках наукової діяльності кафедри української мови Хмельницького національного університету, 3) наукове керівництво аспірантами, проблематика робіт яких пов'язана 3 дослідницькими зацікавленнями керівника-лідера, 4) поширення результатів наукових досліджень у монографіях, статтях, опублікованих у фахових виданнях, доповідях, виголошених на конференціях різного 
рівня тощо, 5) різноаспектне вивчення лідером і членами наукового осередку, наукової школи, що формується, традицій української ономастики, іiі історії, а також новаторські дослідження ще недостатньо розроблених розрядів пропріальної лексики.

Специфіка наукової школи М. Торчинського полягає у використанні оновленої ним класифікаційної структури онімів, особливої термінологічної системи, оновленої методології з актуалізацією квантитативної методики. Про якість наукових робіт М. Торчинського і його послідовників красномовно свідчить високий показник цитування.

Перспективу розвитку ономастичного наукового осередку, яким керує М. Торчинський, убачаємо не тільки у фактичних планах ученого та його підопічних щодо розробки електронної версії словника української ономастичної термінології, але й у багатоаспектному дослідженні різних типів онімів: від традиційних (антропонімів, топонімів, поетонімів) до новітніх - космонімів, назв футбольних команд, найменувань машин і механізмів, власних назв промислових товарів, що може стати основою для нових теоретичних, методологічних чи лексикографічних досліджень у галузі ономастики загалом.

Перспектива репрезентованої в цій статті проблеми полягає в необхідності повного опису досягнень українських ономастичних осередків та українських ономастичних шкіл.

\section{ЛІТЕРАТУРА}

1. Алефиренко Н. Ф. Современные проблемы науки о языке. Москва: Флинта: Наука, 2005. 416 с. 2. Блажчук Ю. I. Антропонімія Уманщини XVII - початку XXI ст.: дис. ... канд. філол. наук: 10.02.01. Київ, 2008. 3. Вербич С. Українська ономастика: перспективи розвитку. Українська мова. 2010. № 3. С. 73-80. 4. Гонца I. С. Ойконімія Черкащини: дис. ... канд. філол. наук: 10.02.01. Умань, 2006. 5. Гонца I. С. Словник ойконімів Уманщини. Умань: Візаві, 2017. 127 с. 6. Григорук Н. В. Власні назви спортивних команд: структура, походження, функціонування в українській мові: дис. ... канд. філол. наук: 10.02.01. Черкаси, 2017. 7. Дергач Д. В. Тенденції дослідження власних назв: від традиції до сучасності. Актуальні проблеми української тінгвістики: теорія і практика. 2008. Вип. 16. С. 100-107. 8. Зубко А. М. Українська ономастика: здобутки та проблеми. Спеціальні історичні дисиипліни: питання теорії та методики. 2007. Вип. 15. С. 262-281. 9. Карпенко Ю. О., Фоміна Л. Ф., Зубов М. І.,

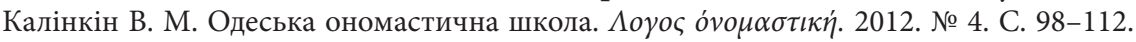
10. Космеда Т. Функційне навантаження наукової мовознавчої школи в сучасному просторі університетської системи. Лінгвістичні студіi. 2017. Вип. 34. С. 176-183. 11. Купчинська 3. Львівська ономастична школа: етапи становлення і перспективи 
розвитку. Вісник Львівського університету. Серія філологічна. 2019. Вип. 71. С. 3-78. 12. Лучик В. В. Актуальні напрями української ономастики. Записки з ономастики. 2011. Вип. 14. С. 126-130. 13. Лучик В. Спроба охопити неохопне. Украйнська мова. 2010. № 2. С. 135-140. 14. Словник української ономастичної термінології / уклад. Д. Г. Бучко, Н. В. Ткачова. Харків: Ранок-НТ, 2012. 256 с. 15. Стрижак А. С. Состояние и перспективы развития ономастики Украины. Перспективы развития славянской ономастики. Москва: Наука, 1980. С. 374-383. 16. Толстой Н. И. Еще раз о «семантике» имени собственного. Актуальные проблемы лексикологии. Минск: Изд-во БГУ, 1970. С. 200-201. 17. Торчинська Н. М., Торчинський М. М. Словник власних географічних назв Хмельницької області. Хмельницький: Авіст, 2008. 549 с. 18. Торчинський М. М. Ойконімія Південно-Західного Поділля: дис. ... канд. філол. наук: 10.02.02. Київ, 1993. 19. Торчинський М. М. Ономастичні дослідження на кафедрі української філології Хмельницького національного університету впродовж 2015-2019 рр. Повідомлення Украӥнської ономастичної комісії. Нова серія. 2019. Вип. 4 (19). С. 5-8. 20. Торчинський М. М. Структура онімного простору української мови. Хмельницький: Авіст, 2008. 548 с. 21. Торчинський М. М. Структура онімного простору української мови. Ч. 2. Функціонування власних назв. Хмельницький: Авіст, 2009. 374 с. 22. Торчинський М. М. Структура, типологія і функціонування онімної лексики української мови: дис. ... докт. філол. наук: 10.02.01. Київ, 2010. 23. Торчинський М. М. Українська ономастика: навч. посіб. Київ: Міленіум, 2010. 238 с. 24. Торчинський Михайло Миколайович. URL: http://lib.khnu.km.ua/inf_res/avtory_HNU/ Torchynskyi.htm. 25. Українська ономастика. URL: http://dn.khnu.km.ua/dn/k_default. aspx?M=k0929\&T=intro\&st=0\&L=1. 26. Ющишина О. М. Прізвищеві назви і прізвища Центральної Хмельниччини: дис. ... канд. філол. наук: 10.02.01. Вінниця, 2019. 27. Янчишин А. М. Власні назви промислових товарів: типологія, походження і функціонування: дис. ... канд. філол. наук: 10.02.01. Черкаси, 2019. 28. Янчура Д. Ономастичні школи в Україні. Studia Ukrainica Posnaniensia. 2018. Vol. VI. C. 45-52. DOI: https://doi. org/10.14746/sup.2018.6.05.

\section{REFERENCES}

1. Alefirenko, N. F. (2005). Sovremennye problemy nauki o yazyke [The current problems in the study of language]. Moskva: Flinta: Nauka [in Russian]. 2. Blazhchuk, Yu. I. (2008). Antroponimiia Umanshchyny XVII - pochatku XXI st. [The anthroponymy of Uman region of the period between the $17^{\text {th }}$ century and the beginning of the $21^{\text {st }}$ century]. Candidate's thesis. Kyiv: NPU im. M. P. Drahomanova [in Ukrainian]. 3. Verbych, S. (2010). Ukrainska onomastyka: perspektyvy rozvytku [The Ukrainian onomastics: the prospects for development]. Ukrainska mova - Ukrainian language, 3, 73-80. 4. Hontsa, I. S. (2006). Oikonimiia Cherkashchyny [The oikonymics of Cherkasy region]. Candidate's thesis. Uman: Umanskyi derzh. ped. un-t im. Pavla Tychyny [in Ukrainian]. 5. Hontsa, I. S. (2017). Slovnyk oikonimiv Umanshchyny [The dictionary of oikonyms of Uman region]. Uman: Vizavi [in Ukrainian]. 6. Hryhoruk, N. V. (2017). Vlasni nazvy sportyvnykh komand: struktura, pokhodzhennia, funktsionuvannia $\mathrm{v}$ ukrainskii movi [The proper names of sports teams: the structure, origin and functioning in the Ukrainian language]. Candidate's thesis. Cherkasy: Cherkaskyi nats. un-t im. Bohdana Khmelnytskoho [in Ukrainian]. 7. Derhach, D. V. (2008). Tendentsii doslidzhennia vlasnykh nazv: vid tradytsii do suchasnosti [The trends 
in studying proper names: from traditional to modern]. Aktualni problemy ukrainskoi linhvistyky: teoriia i praktyka - Actual problems of Ukrainian Linguistics: Theory and Practice, 16, 100-107 [in Ukrainian]. 8. Zubko, A. M. (2007). Ukrainska onomastyka: zdobutky ta problemy [Ukrainian onomastics: achievements and problems]. Spetsialni istorychni dystsypliny: pytannia teorii ta metodyky - Special historical disciplines: questions of theory and methodology, 15, 262-281 [in Ukrainian]. 9. Karpenko, Yu. O., Fomina, L. F., Zubov, M. I. \& Kalinkin, V. M. (2012). Odeska onomastychna shkola [The onomastic school in Odessa].

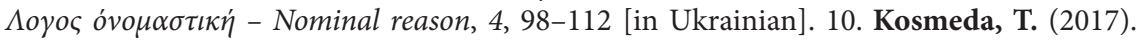
Funktsiine navantazhennia naukovoi movoznavchoi shkoly v suchasnomu prostori universytetskoi systemy [The functional load of a linguistic research school in the modern university system]. Linhvistychni studii - Linguistic Studios, 34, 176-183. 11. Kupchynska, Z. (2019). Lvivska onomastychna shkola: etapy stanovlennia i perspektyvy rozvytku [Lviv onomastic school: stages of establishment and prospects for development]. Visnyk Lvivskoho universytetu. Seriia filolohichna - Bulletin of the University of Lviv. The series is philological, 71, 3-78. [in Ukrainian]. 12. Luchyk, V. V. (2011). Aktualni napriamy ukrainskoi onomastyky [Current directions of Ukrainian onomastics]. Zapysky z onomastyky - Onomastics notes, 14, 126-130 [in Ukrainian]. 13. Luchyk, V. (2010). Sproba okhopyty neokhopne [The attempts to embrace the unembraceable]. Ukrainska mova - Ukrainian language, 2, 135140 [in Ukrainian]. 14. Buchko, D. H. \& Tkachova, N. V. (Ed.). (2012). Slovnyk ukrainskoi onomastychnoi terminolohii [The dictionary of Ukrainian onomastic terminology]. Kharkiv: Ranok-NT [in Ukrainian]. 15. Strizhak, A. S. (1980). Sostoyanie i perspektivy razvitiya onomastiki Ukrainy [The current situation of and the developmental prospects for Ukrainian onomastics]. Perspektivy razvitiya slavyanskoj onomastiki - Prospects for the development of Slavic onomastics, (pp. 374-383). Moskva: Nauka [in Russian]. 16. Tolstoj, N. I. (1970). Eshhe raz o semantike imeni sobstvennogo [Once again about the semantics of a proper name]. Aktual'nye problemy leksikologii - Actual problems of lexicology, (pp. 200-201). Minsk: Izd-vo BGU [in Russian]. 17. Torchynska, N. M., Torchynskyi, M. M. (2008). Slovnyk vlasnykh heohrafichnykh nazv Khmelnytskoi oblasti [The dictionary of geographic names of Khmelnytskyi oblast]. Khmelnytskyi: Avist [in Ukrainian]. 18. Torchynskyi, M. M. (1993). Oikonimiia Pivdenno-Zakhidnoho Podillia [The oikonymics of the south-western Podilia]. Candidate's thesis. Kyiv: Kyivskyi nats. un-t im. Tarasa Shevchenka [in Ukrainian]. 19. Torchynskyi, M. M. (2019). Onomastychni doslidzhennia na kafedri ukrainskoi filolohii Khmelnytskoho natsionalnoho universytetu vprodovzh 2015-2019 rr. [Onomastic research conducted at the Department of the Ukrainian Philology at Khmelnytskyi National University between 2015 and 2019]. Povidomlennia Ukrainskoi onomastychnoi komisii. Nova seriia - Message from the Ukrainian Onomastic Commission. New series, 4 (19), 5-8 [in Ukrainian]. 20. Torchynskyi, M. M. (2008). Struktura onimnoho prostoru ukrainskoi movy [The structure of naming expressions in the Ukrainian language]. Khmelnytskyi: Avist [in Ukrainian]. 21. Torchynskyi, M. M. (2009). Struktura onimnoho prostoru ukrainskoi movy [The structure of naming expressions in the Ukrainian language]. (Vol. 2. Funktsionuvannia vlasnykh nazv - The functioning of proper names). Khmelnytskyi: Avist [in Ukrainian]. 22. Torchynskyi, M. M. (2010). Struktura, typolohiia i funktsionuvannia onimnoi leksyky ukrainskoi movy [The structure, typology and functioning of naming expressions in Ukrainian]. Doctor's thesis. Kyiv: Kyivskyi nats. un-t im. Tarasa Shevchenka [in Ukrainian]. 23. Torchynskyi, M. M. (2010). Ukrainska onomastyka [Ukrainian onomastics]. Kyiv: 
Milenium [in Ukrainian]. 24. Torchynskyi, Mykhailo Mykolaiovych. Retrieved from http:// lib.khnu.km.ua/inf_res/avtory_HNU/Torchynskyi.htm [in Ukrainian]. 25. Ukrainska onomastyka [Ukrainian onomastics]. Retrieved from http://dn.khnu.km.ua/dn/k_default. aspx?M=k0929\&T=intro\&st=0\&L=1 [in Ukrainian]. 26. Yushchyshyna, O. M. (2019). Prizvyshchevi nazvy i prizvyshcha Tsentralnoi Khmelnychchyny [Surname-based proper names and surnames of the central Khmelnytskyi oblast]. Candidate's thesis. Vinnytsia: Donetskyi nats. un-t imeni Vasylia Stusa [in Ukrainian]. 27. Yanchyshyn, A. M. (2019). Vlasni nazvy promyslovykh tovariv: typolohiia, pokhodzhennia i funktsionuvannia [The names of industrial goods: typology, origin and functioning]. Candidate's thesis. Cherkasy: Cherkaskyi nats. un-t im. Bohdana Khmelnytskoho [in Ukrainian]. 28. Yanchura, D. (2018). Onomastychni shkoly v Ukraini [Onomastic schools in Ukraine]. Studia Ukrainica Posnaniensia, VI, 45-52 [in Ukrainian].

Янчура Домініка - магістр, аспірант кафедри україністики Інституту російської й української філології, Університет імені Адама Міцкевича в Познані (Польща); 61874 Poznan, Al. Niepodległości 4.

Tel.: +48731911709

E-mail: dominikajanczura@interia.eu

https://orcid.org/oooo-0001-5634-7044

Janchura Dominika - MA, Postgraduate Student, Departament of Ukrainian Studies, Institute of Russian Philology and Ukrainian Philology, Adam Mitskevych University; Al. Niepodległości 4, Poznań, 61-874, Poland.

Надійшла до редакції 07 лютого 2020 року 